\title{
Polymerase chain reaction and restriction fragment length polymorphism analysis of the ITS2 region for differatiation of Brazilian Biomphalaria intermediate hosts of the Schistosoma mansoni
}

\author{
Reação em cadeia da polimerase e polimorfismo de tamanho de fragmento de restrição da \\ região do ITS2 para a diferenciação dos moluscos brasileiros do gênero Biomphalaria \\ hospedeiros intermediários do Schistosoma mansoni
}

\author{
Teofânia Heloísa Dutra Amorim Vidigal ${ }^{1,2}$, Kelly Grace Magalhães ${ }^{1}$ \\ and Omar dos Santos Carvalho ${ }^{1}$
}

\begin{abstract}
We sequenced the internal transcribed spacer 2 of the ribosomal DNA (ITS2-DNAr) from the three Schistosoma mansoni intermediate hosts in Brazil: Biomphalaria glabrata, Biomphalaria tenagophila and Biomphalaria straminea. Analysis of a restriction map from those sequences allowed us to select putative restriction enzymes able to identify the snail species under study. Four restriction enzymes were used and HpaII provided simple species-specific profiles easily visualized in polyacrylamide gels. The use of ITS2 is advantageous as it provides a small fragment of $460 \mathrm{bp}$ which may be easily amplified by PCR. In the current work, we showed that the amplification of ITS2-DNAr together with HpaII enzyme restriction is an auxiliary molecular tool for the morphological identification of such snails as well as for taxonomic and phylogenetic studies of neotropical planorbids.
\end{abstract}

Key-words: Biomphalaria glabrata. Biomphalaria tenagophila. Biomphalaria straminea. Polymerase chain reaction. Internal transcribed spacer 2.

\section{RESUM0}

0 sequenciamento da região espaçadora transcrita interna 2 do DNA ribossomal (ITS2-DNAr) das espécies brasileiras gênero Biomphalaria (B. glabrata, B. tenagophila and B. straminea) hospedeiras intermediárias do Schistosoma mansoni no Brasil, permitiu a análise dos sítios de restrição presentes nestas seqüências. A análise do mapa de restrição obtido dessas seqüências nos permitiu selecionar enzimas mais promissoras que gerassem perfis de restrição capazes de identificar essas espécies. Foram testadas 4 enzimas e a enzima HpaII foi selecionada por produzir perfis espécie específicos de fácil visualização em gel de poliacrilamida. A utilização da região ITS2 tem como vantagens a obtenção de um fragmento pequeno de 460bp, o qual pode ser facilmente amplificado por PCR. Neste trabalho, nos demonstramos que a amplificação da região ITS2-DNAr e restrição deste com a enzima HpaII é uma ferramenta molecular auxiliar a identificação morfológica desses moluscos, bem como para estudos taxonômicos e filogenéticos de planorbídeos neotropicais.

Palavras-chaves: Biomphalaria glabrata. Biomphalaria tenagophila. Biomphalaria straminea. Reação em cadeia da polimerase. Região espaçadora transcrita interna 2.

\footnotetext{
1. Centro de Pesquisas René Rachou da Fundação Oswaldo Cruz, Belo Horizonte, MG, Brasil. 2. Departamento de Zoologia do Instituto de Ciências Biológicas da Universidade Federal de Minas Gerais, Belo Horizonte, MG, Brasil

Work partially supported by CAPES, FAPEMIG and PIBIC/FIOCRUZ

Address to: Dr. Omar dos Santos Carvalho. CPqRR/FIOCRUZ. Av. Augusto de Lima 1715, 30190-002 Belo Horizonte, MG, Brasil.

Fax: 5531 3295-3115.

e-mail: omar@cpqrr.fiocruz.br

Recebido para publicação em 3/2/2004

Aceito em 20/5/2004
} 
Among the 10 Brazilian snail species and one subspecies of the genus Biomphalaria described up to the present, B. glabrata ${ }^{17}$, B. tenagophila ${ }^{8}$, B. straminea ${ }^{5}$, B. tenagophila guaibensis ${ }^{13}$ B. peregrina ${ }^{8}$, B. kuhniana ${ }^{3}$, B. schrammi ${ }^{4}$, B. amazonica ${ }^{9}$, B. oligoza ${ }^{10}$, B. intermedia ${ }^{16}$ and B. occidentalis ${ }^{12}$ only the first three species have been found naturally infected by Schistosoma mansoni ${ }^{14}$.

The correct identification of Biomphalaria snails is complicated due to the high intra-specific variation in anatomical and morphological characters or great similarity among some species $^{911} 15$. The availability of methodologies based on molecular analysis has enabled the access to more consistent information on Biomphalaria populational structure among Planorbidae. Molecular taxonomy has been able to solve several problems considered insoluble so far by traditional morphology.

The polymerase chain reaction and restriction fragment length polymorphism (PCR-RFLP) analysis of the internal transcribed spacer (ITS) region of the rDNA $(1300 \mathrm{pb}$ approximately) and a part of COI region of mitochondrial DNA (mit-COI - 780bp approximately) have been used for identification of several Biomphalaria species from Brazil and some regions of South America 1218192122 . Restriction enzymes were randomly selected due to the lack of available sequences from Biomphalaria ITS region. Butfor part of the mit-COI region, analysis of a restriction map available in a data base allowed us to select particular enzymes to be tested and used in PCR-RFLP. In the present work, we report the use of this methodology for specific identification of field populations of B. glabrata, B. straminea and B. tenagophila from different Brazilian localities using restriction profiles provided by the ITS2 region. The choice of such region was due to two specific reasons: 1 ) on account of the size of the generated fragment for Biomphalaria, after PCR amplification (approximately 460bp). This is a considerably small product when compared with the size of ITSrDNA and the COI region from this genus, enabling an easier amplification with no need of a high quality DNA; 2) this region proved to be appropriate as it had been sequenced and analyzed in phylogenetic studies of Brazilian Biomphalaria species ${ }^{20}$.

Ten specimens of each population were killed and fixed. Before fixing the specimens, a fragment of their foot was removed for subsequentDNA extraction. Fixed specimens were identified by means of comparative morphology of the reproductive organs and shells ${ }^{1121315}$. Total DNA was extracted from the foot of each snail using the Wizard Genomic DNA Purification Kit (Promega) ${ }^{21}$. The ITS2 region was amplified using the primers ITS2F ( 5 '-CGTCCGTCTGAGGGTCGGTTTGC$3)^{20}$ and ETTS1 (5'-TGCTTAAGTTCAGCGGGT-3') ${ }^{7}$ anchored in the conserved extremities of the $5.8 \mathrm{~S}$ and $28 \mathrm{~S}$ ribosomal genes, respectively. The PCR amplification conditions were the same used by Vidigal et a ${ }^{19}$, except for the annealing temperature, which was $60^{\circ} \mathrm{C}$.

The PCR amplification of Biomphalaria ITS2 region, from four specimens of each species under study, resulted in a product of approximately 460bp. Theses products were digested using the following restriction enzymes: TaqI and MboI (Invitrogen,
Life Science), RsaI and HpaII ( Promega Co, USA). These enzymes were selected based on the restriction map analysis using the program Webcutter version 2.0, (www.firstmarket.com/cutter/ cut2.html) of the ITS2 sequences available in the Genbank ${ }^{20}$. The access numbers used in our study were: B. glabrata, AF198659, AF198660, AF1 98661, AF198662; B. tenagophila AF198654, AF198655, AF198656; B. straminea AF198668, AF198669, AF198670, AF198671, AF198672.

Afterwards, the fragments were visualized in $6 \%$ silver-stained polyacrylamide gels. Digestion and RFLP analysis were performed ${ }^{18}$ and the gels photographed with a Mavica digital camera ( Sony).

The profiles obtained with TaqI and RsaI did not allow us to distinguish between the three species due to the high similarity among RFLP profiles (data not shown). The most promising profiles were those produced by MoI and HapII, and the best result was obtained with HapII (Figure 1), which provided a simple profile of four fragments for B. glabrata, (200, 130, 90 and 70bp), B. tenagophila (200, 120, 90 and 60bp) and two fragments for B. straminea ( 300 and 180bp). Although B. glabrata and B. tenagophila share the fragments of 200 and 90bp (Figure 1), they could be separated by other two nonshared fragments: Bg1 (130bp) and Bg2 (70bp) for B. glabrata; Bt1 (120bp) and Bt2 (70bp) for B. tenagophila. The restriction profile for B. straminea comprised: Bs1 (300bp) and Bs2 (180bp) (Figure 1). Reproducibility of the generated profiles with HapII was supported by the use of specimens originated from different localities in Brazil ( Figure 1).

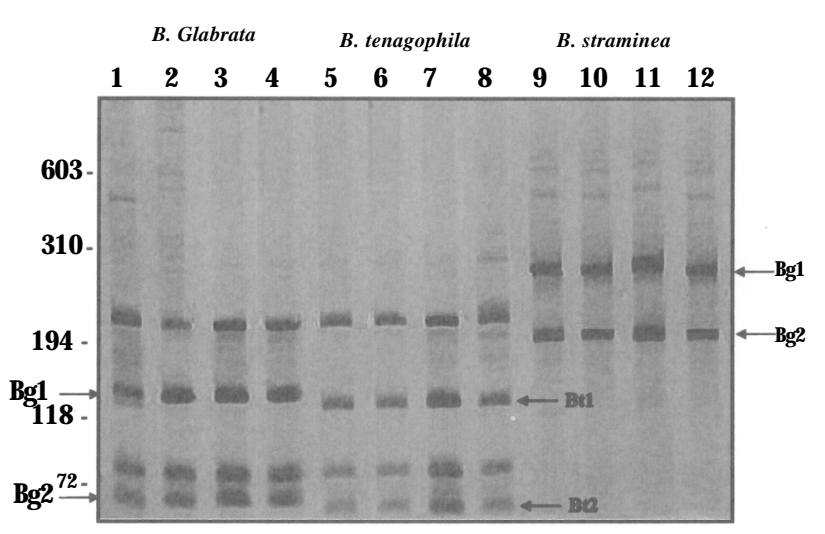

Figure 1 - Silver-stained 6\% polyacrylamide gel showing the restriction profiles obtained with enzyme HpaII of the ITS2 region of DNA extracted from Biomphalaria species intermediate hosts of the S. mansoni in the Brazil. Lane 1: B. glabrata from Touros (State of Rio Grande do Norte); Lane 2: B. glabrata from Cururupu (State of Maranhão); Lane 3: B. glabrata from Jacobina (State of Bahia); Lane 4: B. glabrata from Sabará (State of Minas Gerais); Lane 5: B. tenagophila from Vespasiano (State of Minas Gerais); Lane 6: B. tenagophila from Formosa (State of Goiás); Lane 7: B. tenagophila from Florianópolis ( State of Santa Catarina); Lane 8: B. tenagophila from Imbé (State of Rio Grande do Sul); Lane 9: B. straminea from Picos ( State of Piauí); Lane 10: B. straminea from Jacobina (State of Bahia); Lane 11: B. straminea from Juiz de Fora (State of Minas Gerais); Lane 12: B. straminea from Guaíra (State of Paraná). The arrows and abbreviations indicate species specific fragments. $B$. glabrata: Bg1- 130bp and Bg2- $70 \mathrm{bp}$; B. tenagophila, Bt1- 120bp and Bt2- 70bp and B. straminea, Bs1 300bp and Bs2 180bp. Molecular size markers are shown on the left of each gel. 
These results demonstrated that PCR-RFPP of the ITS2 region, using HpaII restriction enzyme, is an important tool to distinguish among B. glabrata, B. straminea and B. tenagophila species. Such data is in accordance with those produced for ITS and COI regions, through the same technique ${ }^{1922}$ and it also corroborates classical morphological taxonomy.

In general success of the amplification using degraded DNA is difficult to achieve and severely restricted in target size ( degraded DNA results in amplification of relatively small fragments) ${ }^{6}$. Regarding this aspect, we believe that such methodology may be used in studies, in which degraded DNA is recovered from improperly conserved material (low molecular weight < 500bp). Thus, the fragment of 460bp correspondent to the ITS2 region maybe more easily amplified by PCR than a region of approximately 1300bp (approximate size of ITS-rDNA from Planorbidae), due to the need for a more conserved or high quality DNA.

\section{ACKNOWLEDGEMENTS}

To Dra Liana K. Passos from Centro de Pesquias René Rachou/FIOCRUZ who provided us with valuable critical comments.

\section{REFERENCES}

1. Caldeira RL, Vidigal THDA, Martinela L, Simpson AJG, Carvalho OS. Identification of Planorbids from Venezuela by Polymerase Chain Reaction Amplification and Restriction Fragment Length Polymorphism (PCR-RFLP). Memórias do Instituto Oswaldo Cruz 95: 171-177, 2000.

2. Caldeira RL, Vidigal THDA, Paulinelli ST, Simpson AJG, Carvalho OS. Molecular identification of similar species of the genus Biomphalaria (Mollusca: Planorbidae) determined by PCR-RFLP. Memórias do Instituto Oswaldo Cruz 93: 219-225, 1998.

3. Clessin S. Die Familie der Limnaeiden, etc. In: Martini, Cheminitz (eds) Systematisches Conchy - Cabinet, Edition 2, vol. 1, pt. 17. Bauer \& Raspe, Nünberg, 1883-1884.

4. Crosse H. Description d'espéces nouvelles. Journal of Conchyliologie 12: 152-154, 1864.

5. Dunker W. Diagnoses specierum novarum generis Planorbis collectionis Cumingianae. Proceedings of the Zoological Society of London 16: 40-43, 1848, 1996.

6. Golenberg EM, Bickel A, Weihs P Effect of highly fragmented DNA on PCR. Nucleic Acids Research 24: 5026-5033, 1996.

7. Kane RA, Rollinson D Repetitive sequences in the ribosomal DNA internal transcribed spacer of Schistosoma haematobium, Schistosoma intercalatum and Schistosoma mattheei. Molecular Biochemical Parasitology 63: 153-156. 1994.

8. Orbigny A. Synopsis terrestrium et fluviatilium molluscorum, in suo per American Meridionalem itinere collectorum. Magasin de Zoologie Planorbis 26-28, 1835.

9. Paraense WL. Biomphalaria amazonica and B. cousini, two new species of Neotropical planorbid mollusks. Revista Brasileira de Biologia 26: 115126, 1966.

10. Paraense WL. Biomphalaria oligoza N.N. for Tropicorbis philippianus (Dunker) sensu Lucena. Revista Brasileira de Biologia 34: 379-386, 1974.

11. Paraense WL. Estado atual da sistemática dos planorbídeos brasileiros. Arquivos do Museu Nacional do Rio de Janeiro 55:105-128, 1975.

12. Paraense WL. Biomphalaria occidentalis sp.n. from South America (Mollusca Basommatophora Pulmonata). Memórias do Instituto Oswaldo Cruz 76: 199-211, 1981.

13. Paraense WL. Biomphalaria tenagophila guaibensis ssp.n. from southern Brazil and Uruguay (Pulmonata: Planorbidae). I. Morphology. Memórias do Instituto Oswaldo Cruz 79: 465-469, 1984.

14. Paraense WL. Distribuição dos caramujos no Brasil. In: Reis FA, Faria I, Katz N (eds) Modernos conhecimentos sobre a esquistossomose mansônica. Biblioteca da Academia Mineira de Medicina, p.117-128. 1986.

15. Paraense WL. Biomphalaria kuhniana (Clessin, 1883), planorbid mollusc from South America. Memórias do Instituto Oswaldo Cruz 83: 112, 1988.

16. Paraense WL, Deslandes N. Australorbis intermedius sp.n. from Brazil. Revista Brasileira de Biologia 22: 343-350, 1962.

17. Say T. Account of two new genera, and several new species, of fresh water and land shells. Journal of the Academy of Natural Sciences Philadelphia 1: 276-284, 1818.

18. Spatz L, Vidigal THDA, Caldeira RL, Dias Neto E, Cappa SMG, Carvalho OS. Study of Biomphalaria tenagophila tenagophila, B. t. guaibensis and B. occidentalis by polymerase chain reaction amplification and restriction enzyme digestion of the ribosomal RNA intergenic spacer regions. Journal Molluscan Studies 65: 143-149, 1999.

19. Vidigal THDA, Caldeira RL, Simpson AJ, Carvalho OS. Further studies on the molecular systematics of Biomphalaria snails from Brazil. Memórias do Instituto Oswaldo Cruz 95: 57-66, 2000b.

20. Vidigal THDA, Kissinger JC, Caldeira RL, Pires EC, Monteiro E, Simpson, AJ. Carvalho OS. Phylogenetic relationships among Brazilian Biomphalaria species (Mollusca: Planorbidae) based upon analysis of ribosomal ITS2 sequences. Parasitology 121: 611-620, 2000a.

21. Vidigal THDA, Montresor LC, Simpson AJG, Carvalho OS. Polymerase Chain Reaction and Restriction Fragment Length Polymorphism of Cytochrome oxidase I used for differentiation Brazilian Biomphalaria species intermediate host of Schistosoma mansoni. Memórias do Instituto Oswaldo Cruz 97: 47-52, 2002.

22. Vidigal THDA, Spatz L, Nunes DN, Simpson AJG, Carvalho OS, Dias Neto E. Biomphalaria spp: Identification of the intermediate snail hosts of Schistosoma mansoni by polymerase chain reaction amplification and restriction enzyme digestion of the ribosomal RNA gene intergenic spacer. Experimental Parasitology 89: 180-187, 1998. 